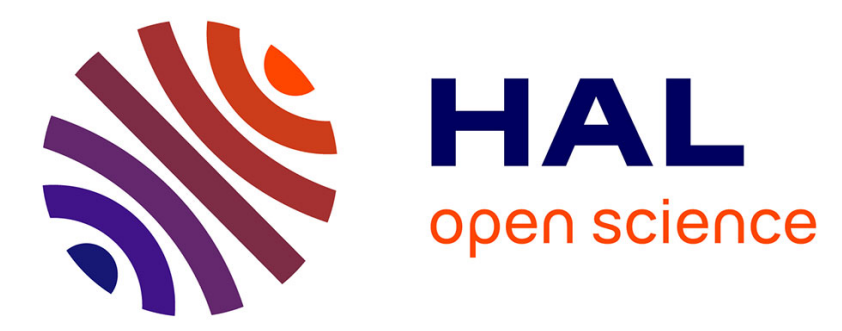

\title{
Synthesis and characterization of a nano-scaled barium cerate perovskite powder using starch as polymerization agent
}

Roberto Köferstein, Dietrich Hesse, Stefan G Ebbinghaus

\section{- To cite this version:}

Roberto Köferstein, Dietrich Hesse, Stefan G Ebbinghaus. Synthesis and characterization of a nanoscaled barium cerate perovskite powder using starch as polymerization agent. Solid State Ionics, 2011, 203 (1), pp.52-56. 10.1016/j.ssi.2011.09.010 . hal-02004740

\author{
HAL Id: hal-02004740 \\ https://hal.science/hal-02004740
}

Submitted on 2 Feb 2019

HAL is a multi-disciplinary open access archive for the deposit and dissemination of scientific research documents, whether they are published or not. The documents may come from teaching and research institutions in France or abroad, or from public or private research centers.
L'archive ouverte pluridisciplinaire HAL, est destinée au dépôt et à la diffusion de documents scientifiques de niveau recherche, publiés ou non, émanant des établissements d'enseignement et de recherche français ou étrangers, des laboratoires publics ou privés. 


\title{
Solid State Ionics 203 (2011) 52-56
}

\author{
(doi:10.1016/j.ssi.2011.09.010)
}

\section{http://dx.doi.org/10.1016/j.ssi.2011.09.010}

\section{Synthesis and characterization of a nano-scaled barium cerate perovskite powder using starch as polymerization agent}

\author{
Roberto Köferstein $^{\mathrm{a},{ }^{*},}$, Dietrich Hesse ${ }^{\mathrm{b}}$, Stefan G. Ebbinghaus ${ }^{\mathrm{c}}$ \\ ${ }^{a}$ Department of Environmental Engineering, Helmholtz Centre for Environmental Research - \\ UFZ, Permoserstr. 15, 04318 Leipzig, Germany. \\ ${ }^{b}$ Max Planck Institute of Microstructure Physics, Weinberg 2, 06120 Halle, Germany. \\ ${ }^{c}$ Institute of Chemistry, Inorganic Chemistry, Martin-Luther-University Halle-Wittenberg, \\ Kurt-Mothes-Strasse 2, 06120 Halle, Germany. \\ * Corresponding author. Tel.: +49-341-2351698; Fax: +49-341-2351471. \\ E-mail address: roberto_koeferstein@web.de
}

\begin{abstract}
The preparation of nano-sized $\mathrm{BaCeO}_{3}$ powder using starch as a polymerization agent is described herein. Phase evolution during the decomposition process of a (BaCe)-gel was monitored by XRD. A phase-pure nano-sized $\mathrm{BaCeO}_{3}$ powder was obtained after calcining of the $(\mathrm{BaCe})$-gel at $920{ }^{\circ} \mathrm{C}$. The resulting powder has a specific surface area of 15.4 $\mathrm{m}^{2} / \mathrm{g}$. TEM investigations reveal particles mainly in the size range of 30 to $65 \mathrm{~nm}$. The shrinkage and sintering behaviour of resulting powder compacts were studied in comparison to a coarse-grained mixed-oxide $\mathrm{BaCeO}_{3}$ powder $\left(\mathrm{S}_{\mathrm{BET}}=2.1 \mathrm{~m} / \mathrm{g}\right)$. Dilatometric measurements show that the beginning of shrinkage of compacts from the nano-sized powder
\end{abstract}


is downshifted by $300{ }^{\circ} \mathrm{C}$ compared to mixed-oxide powder. Compacts from the nano-sized powder reach a relative density of $91 \%$ after sintering at $1450{ }^{\circ} \mathrm{C}$ for $10 \mathrm{~h}$.

Keywords: barium cerate; starch; perovskite; ceramic; sintering; soft-chemistry synthesis

\section{Introduction}

Perovskite materials based on $\mathrm{BaCeO}_{3}$ possess high proton conductivity in humid atmospheres between 600 and $800{ }^{\circ} \mathrm{C}$. Therefore, $\mathrm{BaCeO}_{3}$ based compounds have potential for energy-related applications and they are candidates as electrolyte materials for solid oxide fuel cells (SOFCs) $[1,2,3,4,5,6,7] . \mathrm{BaCeO}_{3}$ based materials are unstable in $\mathrm{CO}_{2}$ and $\mathrm{H}_{2} \mathrm{O}$ containing atmospheres [8,9], which limits the applications for SOFCs. However, Katahira et al. [4] improved the chemical stability in a $\mathrm{CO}_{2}$ environment using $\mathrm{Zr}^{4+}$ as dopant. An enhanced chemical stability against $\mathrm{CO}_{2}$ and water was found both in the systems $\mathrm{BaCe}_{0.7} \mathrm{Nb}_{0.1} \mathrm{Sm}_{0.2} \mathrm{O}_{3-\delta}[10]$ and $\mathrm{BaIn}_{0.1} \mathrm{Y}_{0.2} \mathrm{Ce}_{0.7} \mathrm{O}_{3-\delta}[11]$.

Furthermore, barium cerate can be also applied as a functional material for semiconductor gas sensors [12] and solid solutions of the type $\mathrm{BaTi}_{1-\mathrm{x}} \mathrm{Ce}_{\mathrm{x}} \mathrm{O}_{3}$ can be used for capacitor applications $[13,14,15,16,17]$.

Catalytic activity of $\mathrm{BaCeO}_{3}$ on the oxidation of methane was investigated by Benlhachemi et al. [18] and Рореscu et al. [19]. A $\mathrm{BaCeO}_{3}$ supported ruthenium catalyst shows excellent activity for ammonia synthesis as reported by Yang et al. [20]. Additionally, soot oxidation activity and an improved tolerance to $\mathrm{SO}_{2}$ poisoning were found on an $\mathrm{Ag} / \mathrm{BaCeO}_{3}$ catalyst [21]. Yuan et al. [22] examined the photocatalytic water splitting properties of $\mathrm{BaCeO}_{3}$.

$\mathrm{BaCeO}_{3}$ crystallizes in the perovskite structure and exhibits three phase transitions up to 1000 ${ }^{\circ} \mathrm{C}$ as reported by Knight [23] and Genet et al. [24]. A first transition at $290{ }^{\circ} \mathrm{C}$ leads from a 
primitive orthorhombic perovskite structure (space group: Pmcn) to the body-centred one (Incn), a second at $400{ }^{\circ} \mathrm{C}$ to a rhombohedrally distorted one $(\mathrm{R} \overline{3} \mathrm{c})$ and the last transition at $900{ }^{\circ} \mathrm{C}$ to the cubic perovskite structure $(\operatorname{Pm} \overline{3} \mathrm{~m})$.

Compacts on the basis of $\mathrm{BaCeO}_{3}$ generally reveal only a moderate densification behaviour $[4,25]$. For application such as capacitors or in SOFCs the density of the ceramics must be high $[26,27,28,29,30,31]$. On the other hand, sintering temperatures above $1500{ }^{\circ} \mathrm{C}$ should be avoided because $\mathrm{BaCeO}_{3}$ melts incongruently at $1480{ }^{\circ} \mathrm{C} \pm 5{ }^{\circ} \mathrm{C}$ with the formation of $\mathrm{CeO}_{2}$ and a liquid containing $\mathrm{BaO}[5,32]$.

In general, powders with high specific surface areas can improve the catalytic activity, the densification behaviour of compacts, and lead to ceramic bodies with a fine-grained microstructure [33,34,35]. Kim et al. [36] reported on the effect of fine- and coarse-grained $\mathrm{BaCeO}_{3}$ on the microstructure and the critical current density of a melt-textured $\mathrm{YBa}_{2} \mathrm{Cu}_{3} \mathrm{O}_{7-\mathrm{y}}$. Since the mixed-oxide method mostly results in coarse-grained powders some wet chemical syntheses have been developed to obtain fine-grained or nano-scaled $\mathrm{BaCeO}_{3}$ powders such as various precursor complex methods, solvothermal- and sol-gel syntheses $[29,37,38,39,40,41,42]$. Nano-sized powders via Pechini based routes are reported by Lee at al. [43], Osman et al. [44] and $S u$ et al. [45]. A hydrothermal process using urotropine [46], a sol-gel combustion [47] and an acrylate hydrogelation method [48] lead also to nano- $\mathrm{BaCeO}_{3}$ powders. Almost all of those preparation methods use $\mathrm{Ce}^{3+}$-compounds as starting materials to obtain $\mathrm{BaCeO}_{3}$. On the other hand, it seem to be advantageous to use $\mathrm{Ce}^{4+}$-based starting materials to synthesize $\mathrm{BaTi}_{1-\mathrm{x}} \mathrm{Ce}_{\mathrm{x}} \mathrm{O}_{3}$ solid solutions by wet chemical methods [49].

The aim of this paper is to describe a simple and cheap one-pot synthetic route starting from a $\mathrm{Ce}^{4+}$-compound and using starch as a polymerization agent to obtain nano-sized $\mathrm{BaCeO}_{3}$. We use starch because of its eco friendly character and is a cheap abundant biopolymer. We have examined the phase evolution during the decomposition process. The shrinkage behaviour of resulting $\mathrm{BaCeO}_{3}$ compacts has also been determined. 


\section{Experimental}

\subsection{Material preparation}

$\mathrm{Ba}\left(\mathrm{CH}_{3} \mathrm{COO}\right)_{2}(0.01 \mathrm{~mol}$, Merck $)$ and $\left(\mathrm{NH}_{4}\right)_{2} \mathrm{Ce}\left(\mathrm{NO}_{3}\right)_{6}(0.01 \mathrm{~mol}$, Alfa Aesar $)$ were separately dissolved in $20 \mathrm{ml}$ water. $6 \mathrm{~g}$ soluble starch $(\mathrm{M}=324.30 \mathrm{~g} / \mathrm{mol}$, Sigma-Aldrich $)$ were suspended under stirring in $20 \mathrm{ml}$ water on a heating plate at $100{ }^{\circ} \mathrm{C}$. After 5 min the barium acetate solution was added together with further $3 \mathrm{~g}$ starch. The mixture was stirred and after 5-10 min the temperature of the heating plate was raised to $120{ }^{\circ} \mathrm{C}$. Under stirring the $\left(\mathrm{NH}_{4}\right)_{2} \mathrm{Ce}\left(\mathrm{NO}_{3}\right)_{6}$ solution was slowly added. The resulting mixture was stirred and heated until it became a high viscous orange gel. The gel turned to a light yellow after about 15 min. The obtained (BaCe)-gel was calcined in static air at $920{ }^{\circ} \mathrm{C}$ for $2 \mathrm{~h}$ by a heating rate controlled thermal treatment to yield a nano-sized $\mathrm{BaCeO}_{3}$ powder (1), as described below. Powder 1 was mixed with 5 mass $\%$ of a saturated aqueous solution of polyvinyl alcohol (PVA) as a pressing aid, then the powder was pressed into pellets to a green density of about $2.6 \mathrm{~g} / \mathrm{cm}^{3}$.

For comparative purposes, a coarse-grained $\mathrm{BaCeO}_{3}$ powder (2) was prepared via a conventional mixed-oxide method and the resulting compacts had a green density of about 3.5 $\mathrm{g} / \mathrm{cm}^{3}$ as described and investigated elsewhere [25].

\subsection{Characterization}

X-ray powder diffraction (XRD) patterns were recorded on a STOE STADI MP diffractometer at room temperature using $\mathrm{Co}-\mathrm{K} \alpha_{1}$ radiation. Powder patterns were refined with the profile fitting software PowderCell [50]. Crystallite sizes were determined by XRD line broadening using the Scherrer equation [51] and the integral peak breadth (software suite WinXPOW [52]). The Wilson-equation was used to determine the strain parameter $[52,53]$. Dilatometric investigations (shrinkage) were performed in a flowing synthetic air atmosphere 
(50 ml/min) in a Setaram TMA 92-16.18 dilatometer. Simultaneous thermogravimetric (TG) and differential thermoanalytic (DTA) measurements were achieved in flowing air (30 $\mathrm{ml} / \mathrm{min}$ ) with heating rates of 10 and $1 \mathrm{~K} / \mathrm{min}$ up to $1200^{\circ} \mathrm{C}$ using a Netzsch STA 449 System. The TG/DTA measurements of the decomposition of the (BaCe)-gel was carried out on a sample preheated at $250{ }^{\circ} \mathrm{C}$ for $0.5 \mathrm{~h}$. The specific surface area was determined using nitrogen three-point BET (Nova 1000, Quantachrome Corporation). The equivalent BET particle diameter was calculated assuming the powder particles were spherical or cubic in shape [54]. Transmission electron microscopy (TEM) samples were prepared by dispersing the powder in alcohol under ultrasonic agitation, and collecting it onto a copper TEM grid covered with a carbon membrane. TEM images were recorded with a Philips CM20Twin at an electron energy of $200 \mathrm{keV}$.

\section{Results and discussion}

\subsection{Powder characterization}

Simultaneous TG and DTA investigations were carried out on a $(\mathrm{BaCe})$-gel preheated at 250 ${ }^{\circ} \mathrm{C}$ for $0.5 \mathrm{~h}$ to obtain a slightly hygroscopic black powder. At a fast heating rate of $10 \mathrm{~K} / \mathrm{min}$ (Fig. 1a) we observed a slight weight loss of $4.6 \%$ up to $246{ }^{\circ} \mathrm{C}$ accompanied by a weak endothermic signal. This weight loss is caused by adsorbed water due to the storage of the preheated sample in ambient atmosphere. At higher temperatures a three-step decomposition process until $381{ }^{\circ} \mathrm{C}$ led a weight loss of $68.1 \%$, resulting in the formation of orthorhombic $\mathrm{BaCO}_{3}$ and cubic $\mathrm{CeO}_{2}$ as main products [55] (see also Fig. 2). These processes are accompanied by a weak exothermic DTA signal at $253{ }^{\circ} \mathrm{C}$ (onset) and two intense and sharp DTA peaks with onset temperatures of about 317 and $341{ }^{\circ} \mathrm{C}$ (Fig. 1b). The exothermic peaks at 317 and $341{ }^{\circ} \mathrm{C}$ suggest a self-combustion-like process in which the nitrate ions act as an oxidizing agent, the starch and the acetate ions as fuels. Between 741 and about $995{ }^{\circ} \mathrm{C}$ there is a last weight loss step caused by the reaction of $\mathrm{BaCO}_{3}$ and $\mathrm{CeO}_{2}$ to $\mathrm{BaCeO}_{3}$. The total 
weight loss is $76.1 \%$. TG/DTA investigations with a slow heating rate of $1 \mathrm{~K} / \mathrm{min}$ show that the beginning of the several decomposition steps is shifted to lower temperatures. The beginning of the self-combustion reaction is characterized by a very sharp exothermic signal with an onset temperature of about $282{ }^{\circ} \mathrm{C}$ and a shoulder at $299{ }^{\circ} \mathrm{C}$. The last decomposition step starts at $665{ }^{\circ} \mathrm{C}$ and is finished at $880{ }^{\circ} \mathrm{C}$. The total weight loss of $77.8 \%$ is slightly higher than for the measurement with $10 \mathrm{~K} / \mathrm{min}$. The difference in the total weight losses between both measurements is caused by the slightly hydroscopic nature of the black preheated sample. In both cases the white TG/DTA residues were identified as orthorhombic $\mathrm{BaCeO}_{3}$.

Fig. 2 shows the phase evolution during the thermal decomposition of the yellow amorphous (BaCe)-gel (Fig. 2a). For these XRD investigations the samples of the (BaCe)-gel were heated in a muffle furnace in static air at various temperatures for $1 \mathrm{~h}$ (heating rate $10 \mathrm{~K} / \mathrm{min}$ ) resulting in fluffy powders. Calcination at $300{ }^{\circ} \mathrm{C}$, i.e. below the ignition temperature of the self-combustion process, yielded a black powder showing only reflections of cubic $\mathrm{Ba}\left(\mathrm{NO}_{3}\right)_{2}$ [55] (Fig. 2b). The reflections of $\mathrm{Ba}\left(\mathrm{NO}_{3}\right)_{2}$ disappear at $400{ }^{\circ} \mathrm{C}$ and the resulting yellow powder reveals the diffraction patterns of orthorhombic $\mathrm{BaCO}_{3}$ and cubic $\mathrm{CeO}_{2}$ [55] (Fig. 2c). With increasing calcination temperature the resulting powders gradually turn into a white colour. Since the strongest reflection (111) at about $2 \theta=33.2^{\circ}$ of cubic $\mathrm{CeO}_{2}$ overlaps with the strongest reflections of orthorhombic $\mathrm{BaCeO}_{3}(020 / 211)$ it is difficult to determine the beginning of the formation of $\mathrm{BaCeO}_{3}$. A heat treatment at $900{ }^{\circ} \mathrm{C}$ shows the evolution of reflections at $2 \theta=47.9^{\circ}$ and $59.6^{\circ}$ which do not belong to $\mathrm{CeO}_{2}$ indicating definitely the formation of $\mathrm{BaCeO}_{3}$ [55] (Fig. 2f). Decomposition at $1000{ }^{\circ} \mathrm{C}$ for $1 \mathrm{~h}$ leads to a powder revealing only reflections of orthorhombic $\mathrm{BaCeO}_{3}$ (Fig. 2g).

According to the TG/DTA investigations the temperature for the formation of $\mathrm{BaCeO}_{3}$ depends on the heating rate and soaking time. To obtain a phase pure nano-sized $\mathrm{BaCeO}_{3}$ powder (see Fig. 2h) we calcined the (BaCe)-gel by the following optimised thermal 
treatment in static air: heating to $500{ }^{\circ} \mathrm{C}$ with a heating rate of $10 \mathrm{~K} / \mathrm{min}$, slow heating with 1 $\mathrm{K} / \mathrm{min}$ to $920{ }^{\circ} \mathrm{C}$, holding at this temperature for $2 \mathrm{~h}$ and cooling with $3 \mathrm{~K} / \mathrm{min}$ to room temperature. The white fluffy powder (1) obtained by this procedure has a specific surface area of $\mathrm{S}_{\mathrm{BET}}=15.4 \mathrm{~m}^{2} / \mathrm{g}$ corresponding to an equivalent particle size of $61 \mathrm{~nm}$, which can be considered the average size of the primary particles [56]. We calculated the crystallite size of powder 1 as $41 \mathrm{~nm}$ using the Scherrer equation, representing a volume-weighted average crystallite size [51]. According to the Wilson-equation [53] the root-mean-square-strain was found to be 0.002 . The calculated crystallite size is slightly smaller than the size of the primary particles obtained from the BET data, because the calcination procedure of the (BaCe)-gel leads to closely joined crystallites and surface areas unavailable for nitrogen adsorption, as described elsewhere [57,58]. TEM investigations (Fig. 3) of powder 1 mainly show particles in the range of 30 to $65 \mathrm{~nm}$, which are generally agglomerated. Isolated particles up to about $85 \mathrm{~nm}$ are also observed. Recently, Bhowmick et al. [46] synthesized nano- $\mathrm{BaCeO}_{3}$ by a wet chemical method using urotropine. After heating at $800{ }^{\circ} \mathrm{C}$ for $10 \mathrm{~h}$ they obtained $\mathrm{BaCeO}_{3}$ with an average crystallite size of $75 \mathrm{~nm}$. A combination of both solvothermal and annealing processes at $900{ }^{\circ} \mathrm{C}$ was reported by Chao et al. [39], which resulted in $\mathrm{BaCeO}_{3}$ powder with particles of about $80 \mathrm{~nm}$.

The XRD pattern of the nano-scaled $\mathrm{BaCeO}_{3}$ powder $\mathbf{1}$ (corrected by an internal standard) was refined on the basis of a primitive orthorhombic unit cell (Pmcn) according to Knight et al. $[59,23]$. We calculated the unit cell parameters as $a=877.19 \mathrm{pm}, \mathrm{b}=624.22 \mathrm{pm}, \mathrm{c}=620.78$ $\mathrm{pm}, \mathrm{V}=339.91 \cdot 10^{6} \mathrm{pm}^{3}$. These lattice constants correspond well to previously reported data for pure $\mathrm{BaCeO}_{3}[59,23]$.

For comparison purposes we also investigated a coarse-grained $\mathrm{BaCeO}_{3}$ powder (2) as described elsewhere [25]. That powder results from a conventional mixed-oxide process at $1150{ }^{\circ} \mathrm{C}$ for $4 \mathrm{~h}$ and has a specific surface area of $2.1 \mathrm{~m}^{2} / \mathrm{g}$ and thus an equivalent particle size of $449 \mathrm{~nm}$. 


\subsection{Sintering behaviour and phase transition}

Fig. 4 shows the non-isothermal dilatometric investigations up to $1500{ }^{\circ} \mathrm{C}$. Since the green compacts $1\left(2.6 \mathrm{~g} / \mathrm{cm}^{3}\right)$ and $2\left(3.5 \mathrm{~g} / \mathrm{cm}^{3}\right)$ differ in their densities the values of the relative shrinkage are not directly comparable. Therefore, from the relative shrinkages the evolution of the relative densities depending on temperature was calculated assuming an isotropic shrinkage of the compacts.

Sample 1 begins to shrink at about $920-940{ }^{\circ} \mathrm{C}$ and shows a broad peak in the shrinkage rate curve (inset in Fig. 4) with a maximum at $1290{ }^{\circ} \mathrm{C}$ (rate: $-1.0 \% / \mathrm{min}$ ). The calculated densification increases up to a relative density of $85 \%$ at $1500{ }^{\circ} \mathrm{C}$. The shrinkage of the coarse-grained compact 2 starts at about $1230{ }^{\circ} \mathrm{C}$ and shows two maxima of the shrinkage rate at $1383{ }^{\circ} \mathrm{C}$ and at $1456{ }^{\circ} \mathrm{C}$ with lower rates of $-0.22 \% / \mathrm{min}$ and $-0.33 \% / \mathrm{min}$, respectively [25]. The densification reaches a value of only $61 \%$ of the relative density up to $1500{ }^{\circ} \mathrm{C}$. The shrinkage rates of sample $\mathbf{1}$ and $\mathbf{2}$ indicate that the densification is dominated by sliding processes, because diffusion processes would have only effected the shrinkage rate by less than $0.1 \% / \min [60,61,62]$.

The development of the final bulk densities of ceramic bodies of $\mathbf{1}$ and $\mathbf{2}$ after isothermal sintering at various temperatures with a soaking time of $10 \mathrm{~h}$ is represented in Fig. 5. The bulk densities of the sintered bodies were calculated from their weight and geometric dimensions. The relative bulk densities of the ceramic bodies refer to the single crystal density of 6.36 $\mathrm{g} / \mathrm{cm}^{3}$ [59]. Coarse-grained powder compacts of $\mathbf{2}$ show an insufficient sintering behaviour. Even after sintering at $1500{ }^{\circ} \mathrm{C}$ for $10 \mathrm{~h}$ we do not obtain any dense ceramic bodies but the relative densities remained below $77 \%$ [25]. In contrast, compacts made from the nano-sized powder 1 exhibit an improved sintering behaviour. Sintering at $1450{ }^{\circ} \mathrm{C}(10 \mathrm{~h}$ dwelling time $)$ leads to dense ceramic bodies with a relative bulk density of $91 \%$. Using the same sintering regime compacts made from a fine-grained $\mathrm{BaCeO}_{3}$ powder $\left(\mathrm{S}_{\mathrm{BET}}=5.8 \mathrm{~m}^{2} / \mathrm{g}\right)$ reach up to 
$1450{ }^{\circ} \mathrm{C}$ a relative density of $83 \%$ as reported in [25]. It is to be noted that dense ceramic bodies from the nano-sized powder $\mathbf{1}$ are already obtained at sintering temperatures below $1480{ }^{\circ} \mathrm{C}$, i.e. the peritectic temperature of $\mathrm{BaCeO}_{3}[32]$.

The high sintering activity of powder 1 results from its nano-scaled morphology because of the large amount of grain boundaries, which promote sliding processes (rearrangement). Sliding processes are caused by amorphous or defect-rich grain boundaries $[63,62]$. Dror et al. [64] observed that a high amount of grain boundaries promotes sliding processes and they described the grain boundaries as amorphous areas surrounding crystalline cores.

\section{Conclusion}

We prepared nano-sized $\mathrm{BaCeO}_{3}$ powders using a $\mathrm{Ce}^{4+}$-salt and starch as a polymerization agent. The resulting ( $\mathrm{BaCe}$ )-gel can be decomposed by a heating-rate controlled process at $920{ }^{\circ} \mathrm{C}$ to a phase-pure $\mathrm{BaCeO}_{3}$ powder (1) with a specific surface area of $15.4 \mathrm{~m}^{2} / \mathrm{g}$ and a crystallite size of about $41 \mathrm{~nm}$. TEM images mainly show particles in the range of 30-65 nm. The nano-sized $\mathrm{BaCeO}_{3}$ powder shows an improved sintering behaviour. Dilatometric measurements of compacts reveal that the beginning of the shrinkage is shifted below 1000 ${ }^{\circ} \mathrm{C}$. Dense ceramic bodies (relative density $\geq 90 \%$ ) can be obtained after isothermal sintering at $1450^{\circ} \mathrm{C}(10 \mathrm{~h})$ without any sintering additive.

\section{Acknowledgements}

The authors thanks Dr. Th. Müller for dilatometric and TG/DTA measurements.

\section{Captions}




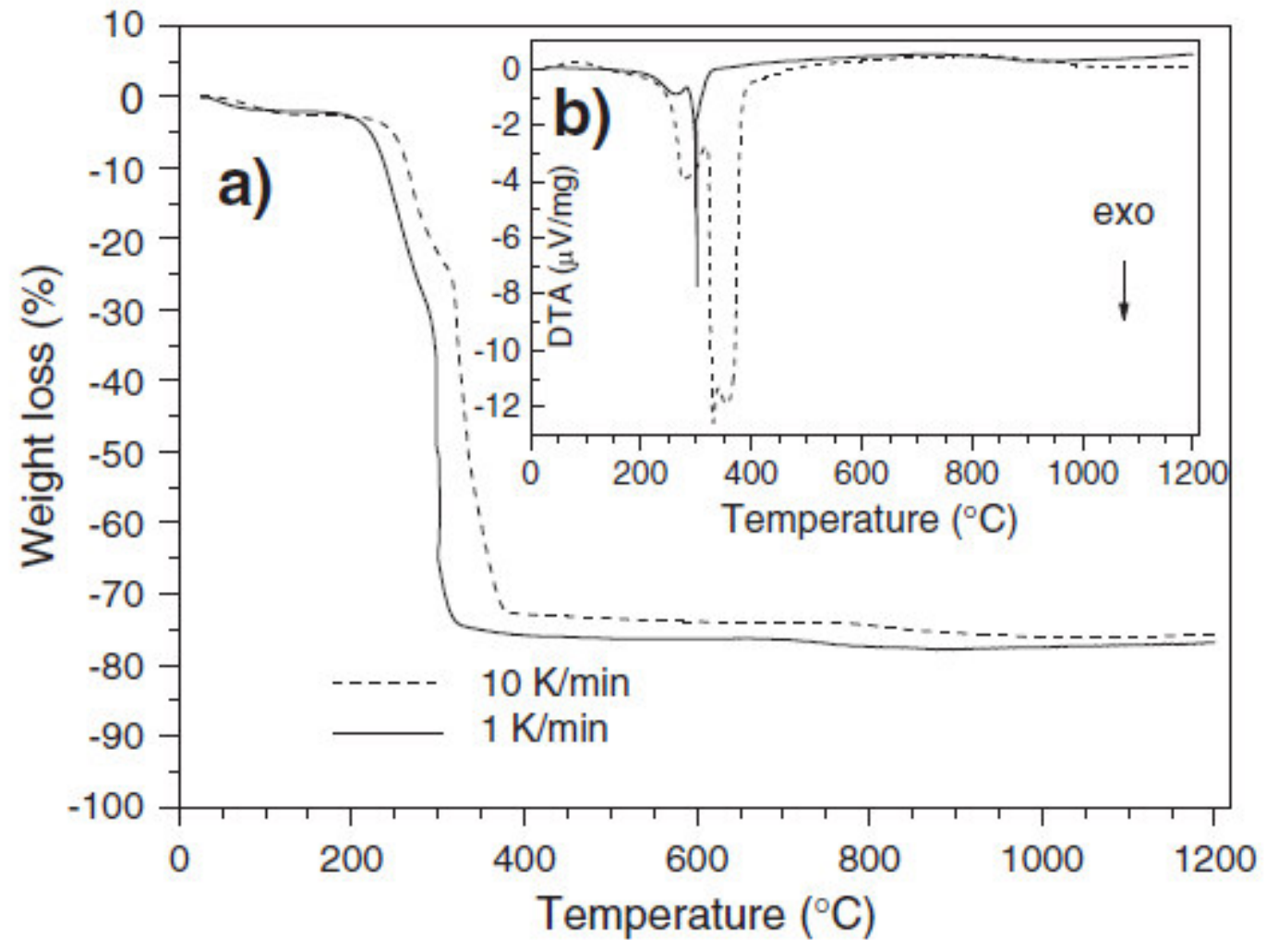

Fig. 1. Simultaneous TG (a) and DTA (b) curves of a preheated (BaCe)-gel in air up to $1200{ }^{\circ} \mathrm{C}$ with heating rates of $10 \mathrm{~K} / \mathrm{min}$ and $1 \mathrm{~K} / \mathrm{min}$, respectively. 


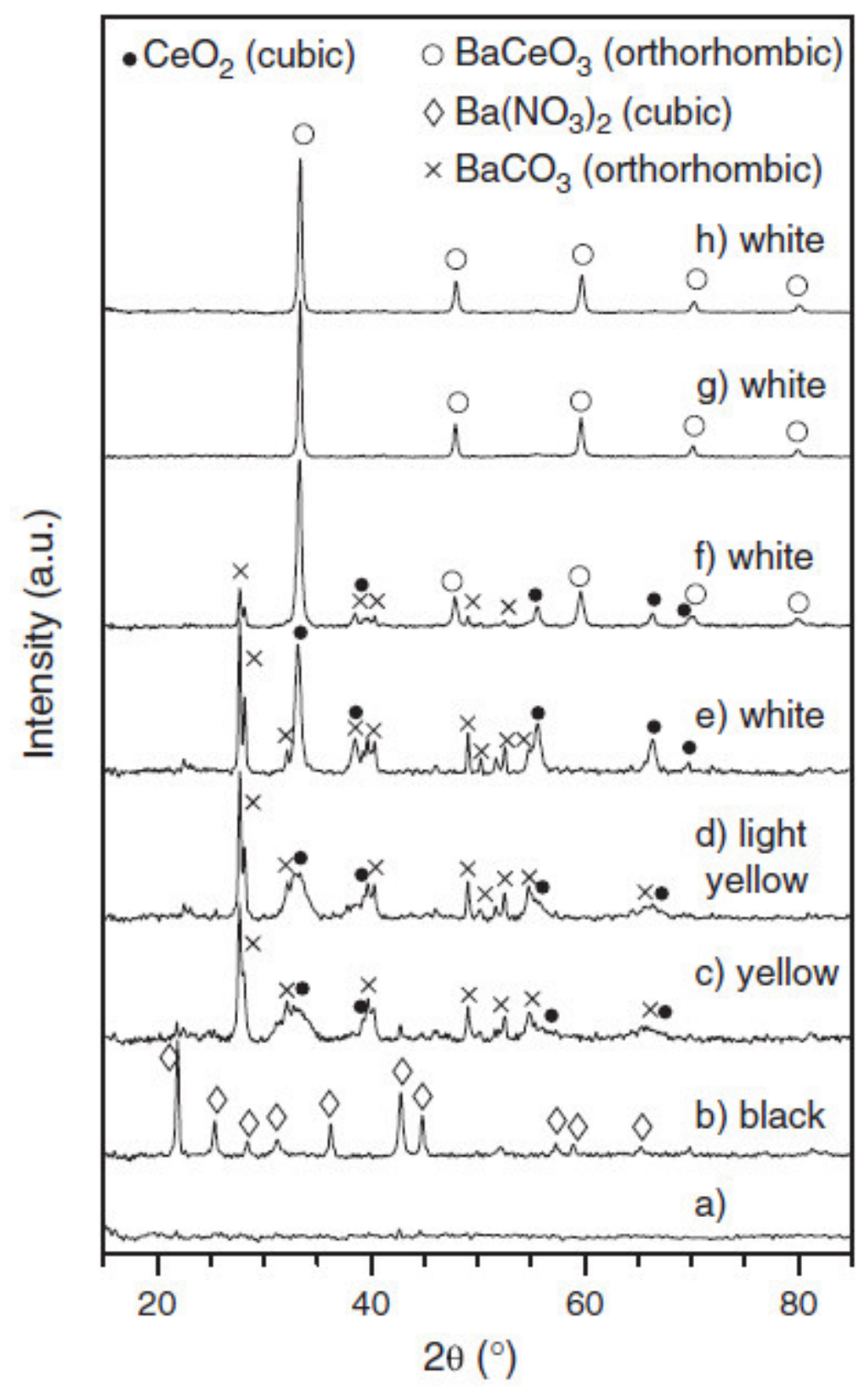

Fig. 2. Room temperature XRD patterns of the (BaCe)-gel (a) and calcination products (b-g) at various temperatures (soaking time $1 \mathrm{~h}$, rate $10 \mathrm{~K} / \mathrm{min}$ ): b) $300{ }^{\circ} \mathrm{C}, \mathrm{c}$ ) $400{ }^{\circ} \mathrm{C}$, d) $600{ }^{\circ} \mathrm{C}$, e) $800^{\circ} \mathrm{C}$. f) $900{ }^{\circ} \mathrm{C}$, g) $1000^{\circ} \mathrm{C}, \mathrm{h}$ ) powder 1 from a heating rate controlled calcination process at $920^{\circ} \mathrm{C}$ for $2 \mathrm{~h}$. 

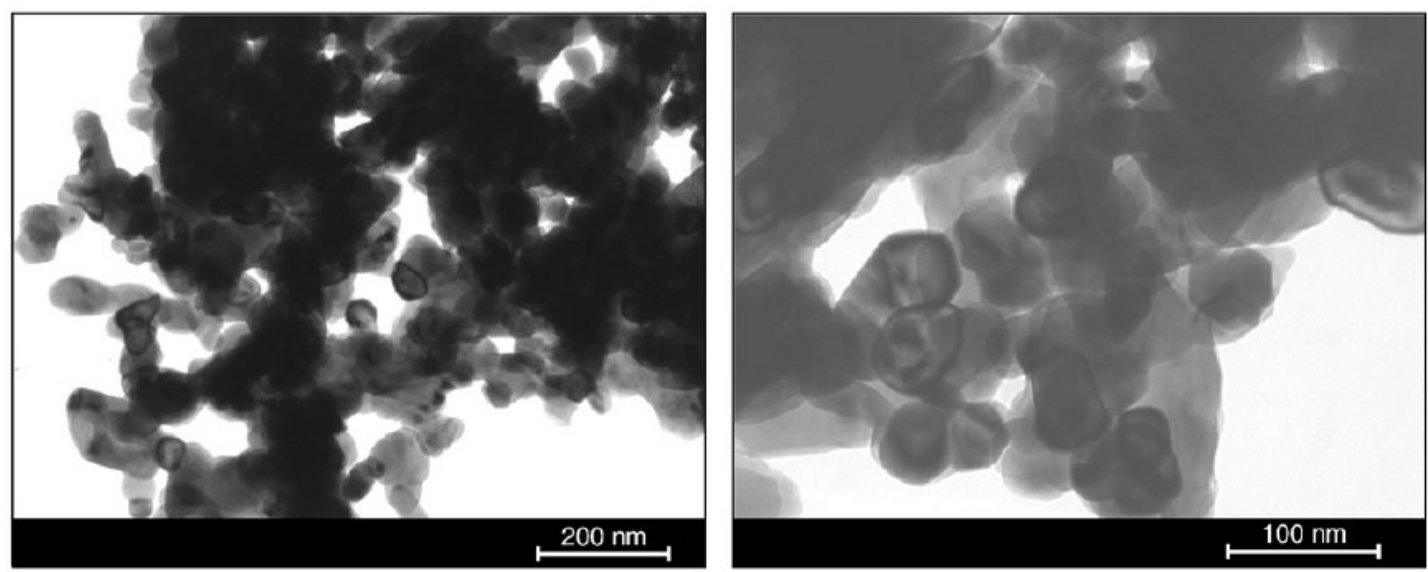

Fig. 3. TEM images of powder $\mathbf{1}$.

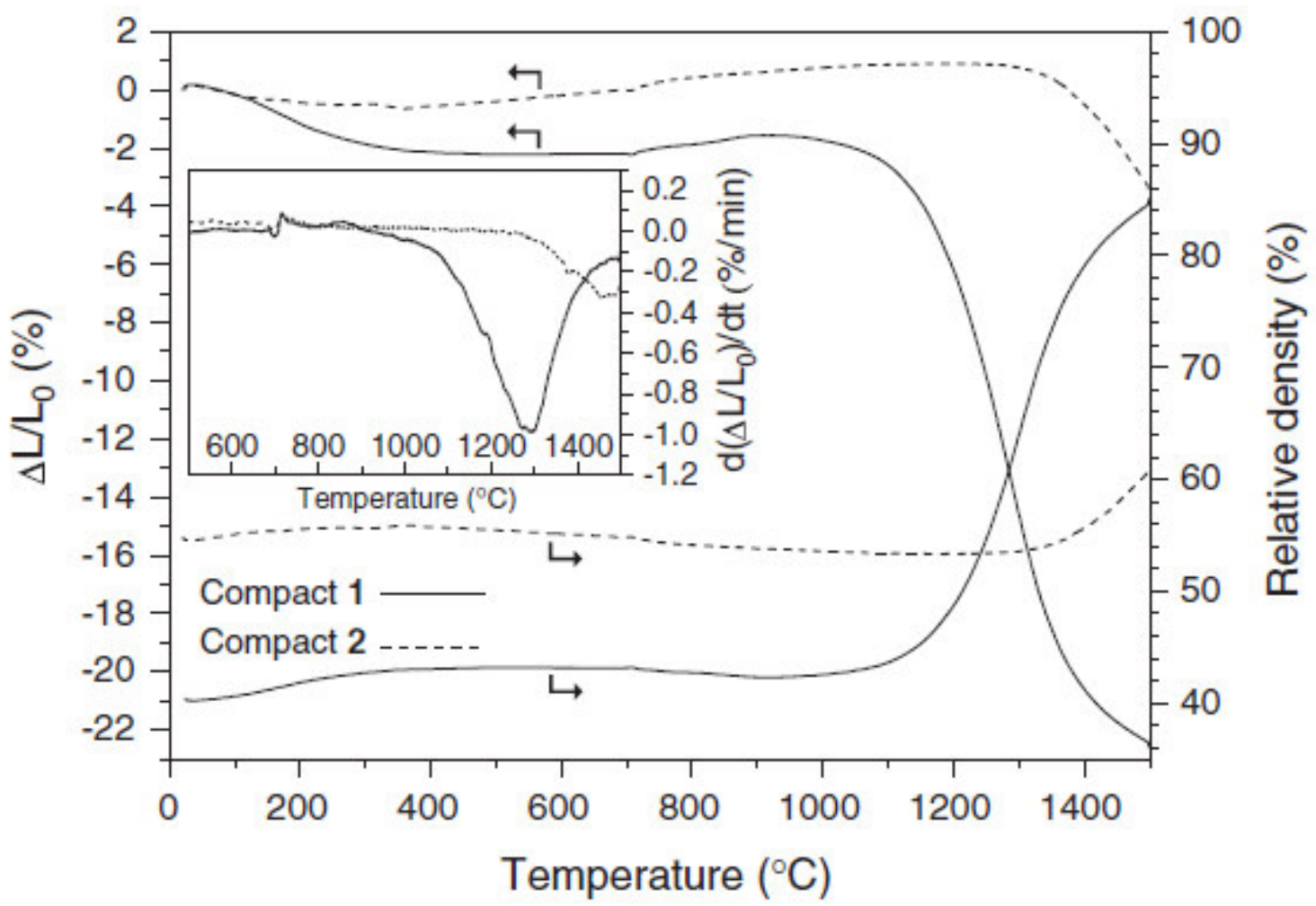

Fig. 4. Non-isothermal dilatometric measurements of green bodies of $\mathbf{1}$ and $\mathbf{2}$ in flowing air (heating rate $10 \mathrm{~K} / \mathrm{min}$ ). The relative densities were calculated assuming an isotropic shrinkage behavior. The inset shows the relative shrinkage rates $\left(d\left(\Delta L / L_{0}\right) / d t\right)$. The green densities are $2.6 \mathrm{~g} / \mathrm{cm}^{3}(1)$ and $3.5 \mathrm{~g} / \mathrm{cm}^{3}(2)$, respectively. 


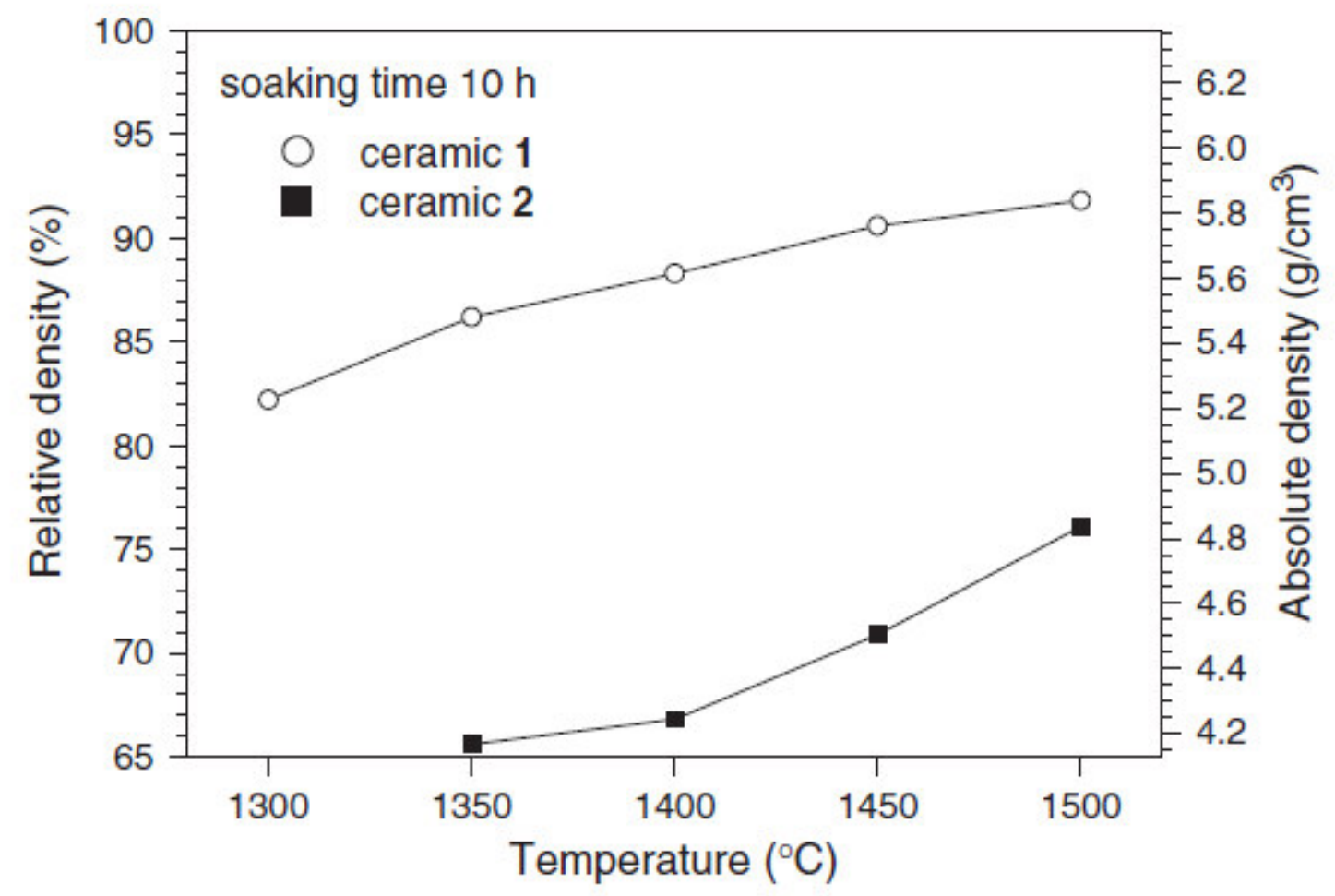

Fig. 5. Final bulk densities versus sintering temperature of ceramic bodies of $\mathbf{1}$ and $\mathbf{2}$ (soaking time: $10 \mathrm{~h}$, heating-/cooling rate: $10 \mathrm{~K} / \mathrm{min}$ ).

\section{References}

[1] Z. Tao, Z. Zhu, H. Wang, W. Liu, J. Power Sources 195 (2010) 3481-3484.

[2] K. Künstler, H.-J.Lang, A. Maiwald, G. Tomandl, Solid State Ionics 107 (1998) 221229.

[3] T. Scherban, W.-K. Lee, A.S. Nowick Solid State Ionics 28-30 (1988) 585-588.

[4] K. Katahira, Y. Kohchi, T. Shimura, H. Iwahara, Solid State Ionics 138 (2000) 91-98.

[5] K.H. Ryu, S.M. Haile, Solid State Ionics 125 (1999) 355-367.

[6] H. Iwahara, H. Uchida, K. Morimoto, J. Electrochem. Soc. 137 (1990) 462-465.

[7] Q. Ma, R. Peng, Y. Lin, J. Gao, G. Meng, J. Power Sources 161 (2006) 95-98.

[8] C.W. Tanner, A.V. Virkar, J. Electrochem. Soc. 143 (1996) 1386-1389. 
[9] M.J. Scholten, J. Schoonman, J.C. van Miltenburg, H.A.J. Oonk, Solid State Ionics 61 (1993) 83-91.

[10] K. Xie, R. Yan, X. Chen, D. Dong, S. Wang, X. Liu, G. Menga, J. Alloy Compd. 472 (2009) 551-555.

[11] F. Zhao, Q. Liu, S. Wang, K. Brinkman, F. Chen, Int. J. Hydrogen Energ. 35 (2010) $4258-4263$.

[12] T. Hibino, H. Iwahara, Sens. Actuators B13-14 (1993) 483-485.

[13] A. Chen, Y. Zhi, J. Zhi, P.M. Vilarinho, J.L. Baptista, J. Eur. Ceram. Soc. 17 (1997) $12-17$.

[14] K. Komatsu (1997) Barium titanium cerium oxide dielectric ceramic composition with high dielectric constant and small dielectric constant shift by temperature changes. JP Patent No. 09157011 A.

[15] P. Baxter, N.J. Hellicar, B. Lewis, J. Am. Ceram. Soc. 42 (1959) 465-470.

[16] D. Kolar, J.P. Guha, M. Buh, Proc. Brit. Ceram. Soc. 23 (1972) 152-158.

[17] D.-Y. Lu, X.-Y. Sun, M. Toda, J. Phys. Chem. Solids 68 (2007) 650-664.

[18] A. Benlhachemi, K. Ouzaouit, H. Benyaich, S. Villain, J.R. Gavarri, Physical \& Chemical News 41 (2008) 50-54.

[19] I. Popescu, I.-C. Marcu, I. Sandulescu, D. Macovei, Prog. Catal. 15 (2006) 79-85.

[20] X.-L. Yang, W.-Q. Zhang, C.-G. Xia, X.-M. Xiong, X.-Y. Mu, B. Hu, Catal. Commun. 11 (2010) 867-870.

[21] K. Ikeue, S. Kobayashi, M. Machida, J. Ceram. Soc. Jpn. 117 (2009) 1153-1157.

[22] Y. Yuan, J. Zheng, X. Zhang, Z. Li, T. Yu, J. Ye, Z. Zou, Solid State Ionics 178 (2008) 1711-1713.

[23] K.S. Knight, Solid State Ionics 74 (1994) 109-117. 
[24] F. Genet, S. Loridant, C. Ritter, G. Lucazeau, J. Phys. Chem. Solids 60 (1999) 20092021.

[25] R. Köferstein, L. Jäger, S. G. Ebbinghaus, J. Mater. Sci. 45 (2010) 6521-6527.

[26] R.W. Rice, Porosity of Ceramics, ed. Marcel Dekker, New York, 1998, pp. 325 et seqq.

[27] Z. He, L. Ma, R. Zhang, Ceram. Int. 30 (2004) 1353-1356.

[28] D.M. Iddles, A.J. Bell, A.J. Moulson, J. Mater. Sci. 27 (1992) 6303-6310.

[29] N. Osman, I.A. Talib, H.A. Hamid, Ionics 15 (2009) 203-208.

[30] E. Gorbova, V. Maragou, D. Medvedev, A. Demin, P. Tsiakaras, J. Power Sources 181 (2008) 292-296.

[31] F.L. Chen, T. Sorensen, G.Y. Meng, D.K. Peng, J. Eur. Ceram. Soc. 18 (1998) 13891395.

[32] J.P. Guha, D. Kolar, J. Mater. Sci. 6 (1971) 1174-1177.

[33] R. Köferstein, L. Jäger, M. Zenkner, T. Müller, H.-P. Abicht, Mater. Chem. Phys. 112 (2008) 531-535.

[34] M. Zenkner, L. Jäger, R. Köferstein, H.-P. Abicht, Solid State Sci. 10 (2008) $1556-1562$.

[35] A.V. Orlov, O.A. Shlyakhtin, A.L. Vinokurov, A.V. Knotko, Y.D. Tretyakov, Inorg. Mater. 41 (2005) 1194-1200.

[36] C.-J. Kim, N. Qadir, A. Mahmood, Y.-H. Han, T.-H. Sung, Physica C 463-465 (2007) $344-347$.

[37] H. Muthurajan, N. Koteswara Rao, U.N. Gupta, S. Pradhan, R.K. Jha, H.H. Kumar, S.A. Mirji, V. Ravi, Mater. Res. Bull. 43 (2008) 1842-1849.

[38] M. Amsif, D. Marrero-López, A. Magrasó, J. Pena-Martínez, J.C. Ruiz-Morales, P. Núnez, J. Eur. Ceram. Soc. 29 (2009) 131-138. 
[39] C. Xu, J. Zhu, X. Yang, L. Lu, X. Wang, J. Rare Earths 26 (2008) 51-54.

[40] J. Cai, K. Laubernds, F.S. Galasso, S.L. Suib, J. Liu, X.-F. Shen, E. Begge, H.R. Kunz, J.M. Fenton, J. Am. Ceram. Soc. 88 (2005) 2729-2735.

[41] A.P. Almeida de Oliveira, J. Hafsaoui, J.F. Hochepied, M.-H. Berger, A. Thorel, J. Eur. Ceram. Soc. 27 (2007) 3597-3600.

[42] H.-L. Lin, R.K. Chiang, C.-L. Kuo, C.-W. Chang, J. Non-Cryst. Solids 353 (2007) $1188-1194$.

[43] D.W. Lee, J.H. Won, K.B. Shim, Mater. Lett. 57 (2003) 3346-3351.

[44] N. Osman, I.A. Talib, H. A. Hamid, Ionics 16 (2010)561-569.

[45] X.T. Su, Q.-Z. Yan, X.-H. Ma, W.-F. Zhang, C.-C. Ge, Solid State Ionics 177 (2006) $1041-1045$.

[46] S. Bhowmick, J. Basu, Y. Xue, C. B. Carter, J. Am. Ceram. Soc. 93 (2010) 40414046.

[47] Q. Feng, X.H. Ma, Q.Z. Yan, C.C. Ge, Mater. Sci. Eng. B 162 (2009) 53-58.

[48] Z. Khani, M. Taillades-Jacquin, G. Taillades, M. Marrony, D.J. Jones, J. Roziere, J. Solid State Chem. 182 (2009) 790-798.

[49] M. Cernea, O. Monnereau, P. Llewellyn, L. Tortet, C. Galassi, J. Eur. Ceram. Soc. 26 (2006) 3241-3246.

[50] W. Kraus, G. Nolze, Powder Diffr. 13 (1998) 256-259.

[51] Th.H. De Keilser, E.J. Mittermeijer, H.C.E Rozendaal, J. Appl. Cryst. 16 (1983) $309-316$.

[52] Program WinXPOW v1.06, Stoe \& Cie GmbH, Darmstadt (1999).

[53] A.R. Stokes, A.J.C. Wilson, Proc. Phys. Soc. 56 (1944) 174-181.

[54] V.D. Allred, S.R. Buxton, J.P. McBride, J. Phys. Chem. 61 (1957) 117-120. 
[55] PDF 2 (International Centre for Diffraction Data, Pennsylvania) 2001, $\mathrm{BaCeO}_{3}$ [822425], $\mathrm{BaCO}_{3}[5-378], \mathrm{CeO}_{2}$ [75-76], $\mathrm{Ba}\left(\mathrm{NO}_{3}\right)_{2}$ [76-1376].

[56] M.T. Buscaglia, M. Bassoli, V. Buscaglia, R. Alessio, J. Am. Ceram. Soc. 88 (2005) $2374-2379$.

[57] V. D. Allred, S. R. Buxton, J. P. McBride, J. Chem. Phys. 61 (1957) 117-120.

[58] R. C. Garvie, J. Phys. Chem. 69 (1965) 1238-1243.

[59] K.S. Knight, N. Bonanos, Mater. Res. Bull. 30 (1995) 347-356.

[60] R. Köferstein, L. Jäger, M. Zenkner, S.G. Ebbinghaus, J. Eur. Ceram. Soc. 29 (2009) $2317-2324$

[61] R. Köferstein, L. Jäger, M. Zenkner, T. Müller, S.G. Ebbinghaus, J. Eur. Ceram. Soc. 30 (2010) 1419-1425.

[62] W. Schatt, Sintervorgänge. VDI-Verlag, Düsseldorf, 1992, pp. 78-100.

[63] W. Schatt, Z. Metallkde. 80 (1989) 809-816.

[64] Y. Dror, R. D. Levi, S. Baltianski, Y. Tsur, J. Electrochem. Soc., 153 (2006) F137-F143. 